Atouts et outils de l'ethnologie des techniques

\title{
Fonderies ouest-africaines. Classement comparatif et tendances
}

Bruno Martinelli

\section{(2) OpenEdition \\ Journals}

Édition électronique

URL : https://journals.openedition.org/tc/622

DOI : $10.4000 /$ tc. 622

ISSN : 1952-420X

Éditeur

Éditions de l'EHESS

\section{Édition imprimée}

Date de publication : 1 septembre 1994

ISSN : 0248-6016

\section{Référence électronique}

Bruno Martinelli, «Fonderies ouest-africaines. Classement comparatif et tendances », Techniques \& Culture [En ligne], 21 | 1994, mis en ligne le 30 décembre 2005, consulté le 29 septembre 2022. URL http://journals.openedition.org/tc/622 ; DOI : https://doi.org/10.4000/tc.622

Ce document a été généré automatiquement le 29 septembre 2022.

Tous droits réservés 
Fonderies ouest-africaines. Classement comparatif et tendances

Bruno Martinelli 